\title{
Effects of the cytokines on the proliferation of and collagen synthesis by human cataract lens epithelial cells
}

\author{
Okihiro Nishi, Kayo Nishi, Tsutomu Fujiwara, Eiichi Shirasawa, Yasukazu Ohmoto
}

\begin{abstract}
Aims-To assess the effects of the cytokines, interleukin-1 (IL-1), IL-1 receptor antagonist (IL-1 ra), transforming growth factor- $\beta 2$ (TGF- $\beta 2$ ) and basic fibroblast growth factor (b-FGF), on the mitosis of and collagen synthesis by lens epithelial cells (LECs) of human cataracts.

Methods-The anterior lens capsule with attached LECs was obtained by capsulotomy during cataract surgery and cultured. The cultures at 2 to 3 weeks before confluency were used for the experiments. To quantify the mitosis and collagen synthesis, the incorporation of ${ }^{3} \mathrm{H}$-thymidine and ${ }^{3} \mathrm{H}$-proline, respectively, into the LECs was measured by a scintillation counter at 48 hours and 24 hours, respectively, after addition of the cytokine at various concentrations into the incubation medium.

Results-IL-1 and b-FGF increased the mitosis and collagen synthesis significantly, but IL-1 ra significantly decreased the mitosis while leaving the collagen synthesis intact. TGF- $\beta 2$ decreased the mitosis significantly, but increased the collagen synthesis significantly.

Conclusion-These cytokines may play an important role in an autocrine or paracrine pathway in the proliferation of residual LECs after cataract surgery. Elucidation of the role of these cytokines may lead to the development of new therapies for the prevention of secondary cataract.
\end{abstract}

(Br F Ophthalmol 1996; 80: 63-68)

Residual lens epithelial cells (LECs) proliferate in a defective lens capsule after cataract surgery, resulting in secondary cataract. They can also undergo fibrous metaplasia and produce collagen, resulting in capsular fibrosis that represents a form of secondary cataract. We reported previously that cultured human cataract LECs obtained by anterior capsulotomy during cataract surgery produce interleukin-1 (IL-1), ${ }^{1}$ IL-6, ${ }^{2}$ IL-8 (unpublished data), basic fibroblast growth factor (b-FGF), ${ }^{3}$ and transforming growth factor- $\beta$ (TGF- $\beta$ ) (unpublished data) in the incubation medium. Cytokines act generally in an autocrine or paracrine manner on the target cells. In this paper, we examined the effect of the cytokines, IL-1, IL-1 receptor antagonist (IL-1 ra), TGF$\beta 2$ and b-FGF, on the proliferation of and collagen synthesis by human cataract LECs in culture.

\section{Materials and methods}

As an indicator of the mitosis rate of the LECs and their collagen synthesis rate, the uptake of ${ }^{3} \mathrm{H}$-thymidine and ${ }^{3} \mathrm{H}$-proline by the cells was measured. The uptake by the LECs when a cytokine at various concentrations was added to the culture was compared with that of the controls without addition of any cytokine.

\section{CULTURE OF HUMAN CATARACT LECS}

Human cataract LECs were cultured as previous described. ${ }^{1}$ Briefly, a circular piece of the anterior capsule with LECs attached was obtained by capsulotomy during cataract surgery and cultured directly without dispersion of the cells. After circular capsulorhexis, the piece of capsule, about $5 \mathrm{~mm}$ in diameter, was touched with an irrigation/aspiration tip and withdrawn from the eye by aspiration. The piece of capsule was held with fine forceps and washed thoroughly with irrigating solution. Each piece of anterior capsule was placed immediately into a well of a 48 well, multiwell plate containing $0.5 \mathrm{ml}$ of Eagle's minimum essential medium (MEM) supplemented with $10 \%$ fetal calf serum (FCS), penicillin $\mathrm{G}$ at $100 \mathrm{U} / \mathrm{ml}$, and streptomycin sulphate at $100 \mu \mathrm{g} / \mathrm{ml}$ and then cultured in $100 \%$ humidity at $37^{\circ} \mathrm{C}$ in a $5 \%$ carbon dioxide atmosphere. The medium was changed weekly. The specimens from patients aged between 55 and 69 years were used for the entire experiment.

CELL HARVEST IN THE TIME COURSE AND DETERMINATION OF THE NUMBER OF VIABLE CELLS IN CULTURE

To determine the cell harvest in the time course, the number of viable cells in each culture was counted (see below) in a separate 
group of cultures at the beginning $(n=8), 1$ $(n=8), 2(n=6), 2^{1 / 2}(17$ days $)(n=6), 3(n=6)$, $3 \frac{1}{2}$ (24 days), $4(n=6)$, and 5 weeks $(n=4)$ of culture. Before the cell count procedure, each culture was photographed under an inverted phase contrast microscope (MFA 20/100, Nikon, Tokyo, Japan) with a video camera. To obtain the entire culture area in a glance, an objective with a magnification $\times 2$ was used. The microphotographs recorded on video tape were incorporated into the device for automated morphometry of corneal endothelial cells using an image analyser ${ }^{4}$ to determine the cell culture area. After obtaining the number of viable cells and the value of cell area in these cultures, the regression equation between them for the cultures at 2 to $3^{1 / 2}$ weeks was determined for the estimation of the number of viable cells in each culture that was used for the subsequent experiment.

\section{COUNT OF VIABLE CELLS}

At each end of the culture, the number of viable cells was counted in each well according to our previously reported procedure. ${ }^{1}$

The incubation medium in each well was removed, followed by a wash with $0.5 \mathrm{ml}$ of calcium free and magnesium free phosphate buffered saline (PBS $(-))$. The cells in each well were then incubated with $0.4 \mathrm{ml}$ of a mixture of $0.25 \%$ trypsin and $0.02 \%$ ethylene diaminotetra-acetic acid (EDTA) sodium for 10 minutes at $37^{\circ} \mathrm{C}$. After repeated pipetting to remove the cells from the capsule and the plastic wall of the well, the entire cell suspension was transferred into a small glass test tube, taking care to leave as few cells as possible in the well. The cells were stained by adding $0.1 \mathrm{ml}$ of a mixture of $0.05 \%$ crystal violet and $2 \cdot 1 \%$ citric acid, followed by one drop of formalin. Only viable cells could be stained by this procedure. The number of viable cells in the cell suspension from each well was determined, in triplicate, in a FuchsRosenthal cell chamber for counting erythrocytes, and the mean value was used to obtain the total number of viable cells in each sample.

\section{UPTAKE OF ${ }^{3} \mathrm{H}$-THYMIDINE BY HUMAN} CATARACT LECS

The mitosis of LECs was assessed by measurement of ${ }^{3} \mathrm{H}$-thymidine incorporation into the cells. The cultures at 2 to 3 weeks, which showed no confluency and were still proliferating, were used. Before the procedure, the culture area in each well was determined in order to read the number of viable cells from the regression equation described.

\section{Addition of the cytokine}

An aliquot of the culture medium was replaced with $0.5 \mathrm{ml}$ culture medium containing the cytokine at various concentrations. Accordingly, human recombinant IL-1 $\alpha(0.5 \mu \mathrm{g} / \mathrm{ml}$, Genzyme, Cambridge, MA, USA) was added at the concentration of 1,10 , and $100 \mathrm{pg} / \mathrm{ml}$ and $1 \mathrm{ng} / \mathrm{ml}$; human recombinant IL-1 ra (1 $\mathrm{mg} / \mathrm{ml}$, Otsuka Pharmaceutical, Tokushima, Japan) at 1,10 , and $100 \mu \mathrm{g} / \mathrm{ml}$; human recombinant TGF- $\beta 2$ (1 $\mathrm{ng} / \mathrm{ml}$, Austral Biologicals, San Ramon, CA, USA) at 10 and $100 \mathrm{pg} / \mathrm{ml}$ and $1 \mathrm{ng} / \mathrm{ml}$; or human recombinant b-FGF ( $1 \mathrm{ng} / \mathrm{ml}$ UBI, Lake Placid, NY, USA) at 1,10 , and $100 \mathrm{ng} / \mathrm{ml}$.

Five to six cultures were used at each concentration. No cytokine was added to six cultures which served as the controls.

\section{${ }^{3} \mathrm{H}$-thymidine labelling and mitosis assay}

After incubating for 48 hours at $37^{\circ} \mathrm{C}$ in a $5 \%$ carbon dioxide atmosphere following cytokine addition, cells were labelled with $0.2 \mu \mathrm{Ci} / \mathrm{ml}$ of ${ }^{3} \mathrm{H}$-thymidine $(1 \mathrm{mg} \mathrm{Ci} / \mathrm{ml})$ for 16 hours; ${ }^{3} \mathrm{H}$-thymidine incorporation into the cells was measured by a standard procedure. ${ }^{5}$

The radioactivity of ${ }^{3} \mathrm{H}$-thymidine was expressed as disintegrations per minute $(\mathrm{dpm}) / 10^{4}$ cells using the value of the viable cells at the end of the culture, which was determined from the regression equation described.

\section{UPTAKE OF ${ }^{3} \mathrm{H}$-PROLINE BY HUMAN CATARACT} LECs

Collagen synthesis was assessed by ${ }^{3} \mathrm{H}$-proline incorporation according to the method of Agelli et $a l^{6}$ with some slight modifications.

\section{Addition of the cytokine}

The medium was removed and washed with PBS $(-)$ twice and replaced with the prolinefree Eagle's MEM (controls) or proline-free Eagle's MEM containing the cytokine at various concentrations. Accordingly, human recombinant IL-1 at concentrations of 10 and $100 \mathrm{pg} / \mathrm{ml}$ and $1 \mathrm{ng} / \mathrm{ml}$; human recombinant IL-1 ra at 1,10 , and $100 \mu \mathrm{g} / \mathrm{ml}$; human recombinant TGF- $\beta 2$ at $100 \mathrm{pg} / \mathrm{ml}$ and 1 and 10 $\mathrm{ng} / \mathrm{ml}$; or human recombinant b-FGF 2 at 1 , 10 , and $100 \mathrm{ng} / \mathrm{ml}$ was added. Five to six cultures were used for each concentration. No cytokine was added to six cultures that served as the controls. These cultures were then incubated overnight.

\section{${ }^{3} \mathrm{H}$-proline labelling}

For radioactive labelling of the collagens synthesised by LECs, $2 \mu \mathrm{Ci} / \mathrm{ml}{ }^{3} \mathrm{H}$-proline (1.04 T Bq/mM, Amersham, Tokyo, Japan), $100 \mu \mathrm{g} / \mathrm{ml} \mathrm{L-ascorbic} \mathrm{acid,} \mathrm{and} 100 \mu \mathrm{g} / \mathrm{ml}$ $\beta$ aminopropionitrile (Daiichi Chemicals Inc, Tokyo, Japan) were added to the medium and then the cells were incubated for a further 6 hours. The medium was then removed and kept in a polyethylene tube. The cells were washed with $\mathrm{PBS}(-)$ and then dissolved by $0.5 \mathrm{~N}$ sodium hydroxide for 10 minutes and put into the same tube as the medium. Twenty $\mu$ l of bovine serum albumin (BSA) $(2 \mathrm{mg} / \mathrm{ml})$ were added as a carrier to the tube. The entire contents were diluted with $0.1 \mathrm{M}$ acetic acid and then distilled water to remove 


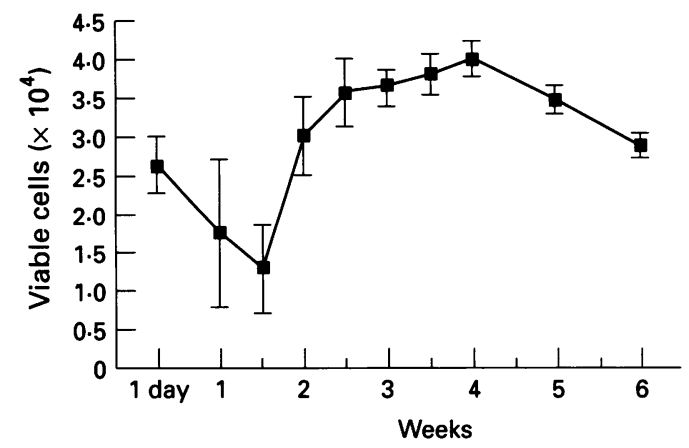

Culture duration

Figure 1 Cell harvest in the time course of cultured human lens epithelial cells obtained during cataract surgery. Each value indicates the mean number of viable cells with standard deviation.

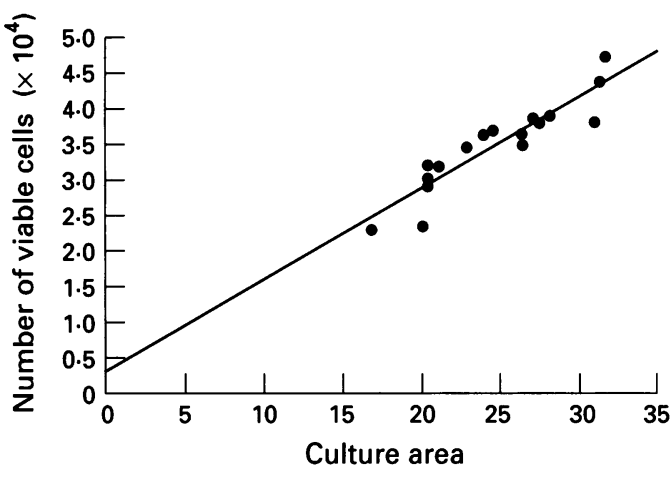

Figure 2 The regression equation between the number of viable cells and the culture area at 2 to $3 \frac{1}{2}$ weeks of culture.

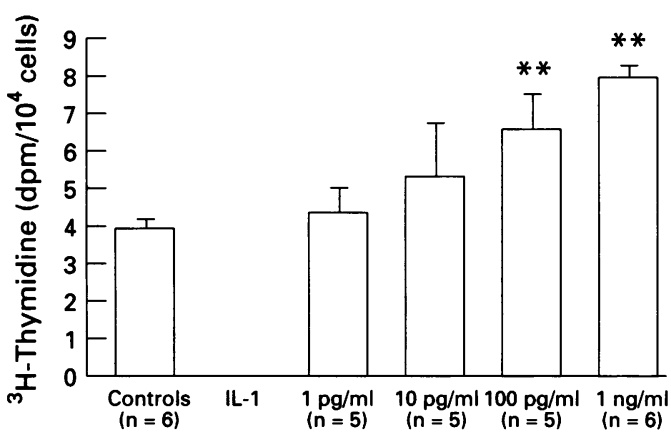

Figure 3 The effects of IL-1 on ${ }^{3} \mathrm{H}$-thymidine uptake by human cataract lens epithelial cells. ${ }^{\star}$ Indicates $p<0 \cdot 01$.

the unincorporated ${ }^{3} \mathrm{H}$-proline and then dried and frozen.

\section{Collagen synthesis assay}

The frozen material was dissolved in $900 \mu \mathrm{l}$ of a solution containing $50 \mathrm{mM}$ Tris- $\mathrm{HCl}$ (pH 7.4), $5 \mathrm{mM} \mathrm{CaCl}_{2}$, and $40 \mu \mathrm{l}$ of $62.5 \mathrm{mM}$ $\mathrm{N}$-ethyl-maleimide (NEM); the solution was divided equally into two tubes. Collagenase solution containing $100 \mu \mathrm{l}$ of $25 \mathrm{mM} \mathrm{CaCl}_{2}$, $62.5 \mu l$ of $0.5 \mathrm{M}$ Tris buffer, $200 \mu \mathrm{l}$ of 62.5 $\mathrm{mM}$ NEM, and $50 \mu \mathrm{l}$ of collagenase stock solution (3000 units/ml $50 \mathrm{mM}$ Tris (pH 7·4)) (Sigma, St Louis, MO, USA) was added into one tube, which was then incubated at $37^{\circ} \mathrm{C}$ for 2 hours. The solution in the tube that served as control received distilled water instead of the collagenase solution and was incubated for 2 hours at $37^{\circ} \mathrm{C}$. Both samples were then cooled with ice and then $400 \mu$ l of $10 \%$ trichloroacetic acid were added to each to

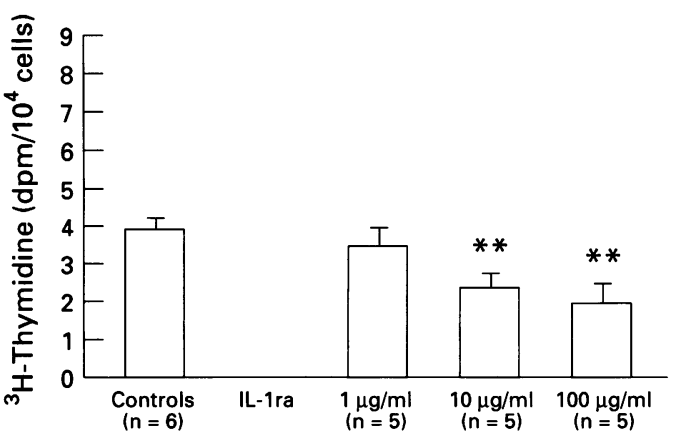

Figure 4 The effects of IL-1ra on ${ }^{3} \mathrm{H}$-thymidine uptake by human cataract lens epithelial cells. ${ }^{\star *}$ Indicates $p<0 \cdot 01$.

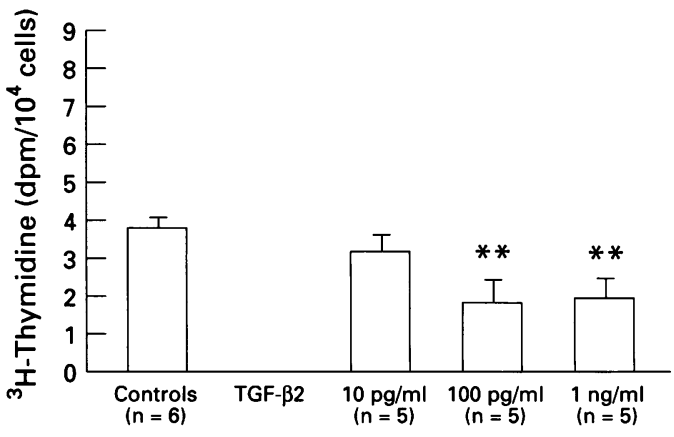

Figure 5 The effects of TGF- $\beta 2$ on ${ }^{3} \mathrm{H}$-thymidine uptake by human cataract lens epithelial cells. **Indicates $p<0.01$.

precipitate the proteins. Each sample was then centrifuged at $14000 \mathrm{rpm}$ for 5 minutes. Radioactivities in the supernatants were measured by a liquid scintillation counter (B460CD, Packard Japan, Tokyo, Japan). The pellets were dissolved with $200 \mu$ l of $0.5 \mathrm{~N}$ sodium hydroxide; their radioactivity was measured to quantify radiolabelled non-collagenous proteins.

Collagens synthesised by LECs were quantified by subtracting the radioactivity in the supernatants incubated without collagenase from that in the supernatants incubated with collagenase. The amount of synthesised collagens was expressed as $\mathrm{dpm} / 10^{4}$ cells using the value of the viable cells at the end of the culture, which was determined from the regression equation described.

STATISTICS

One way ANOVA (Scheffe's method) was used to study dose dependent differences within the different cytokine groups.

\section{Results}

CELL HARVEST IN THE TIME COURSE AND DETERMINATION OF THE NUMBER OF VIABLE CELLS IN CULTURE

Figure 1 shows the cell harvest in the time course of culture. The number of initially viable cells decreased at 1 and $1 \frac{1}{2}$ weeks of culture with a large standard deviation (SD), but increased towards 4 weeks with the decreasing SD and then decreased slightly at 5 and 6 weeks of culture. The regression equation between the number of viable cells and the culture area for the cultures at 2 to $3 \frac{1}{2}$ weeks was $y=0.126 x+0.375 \quad(y=$ number of viable 


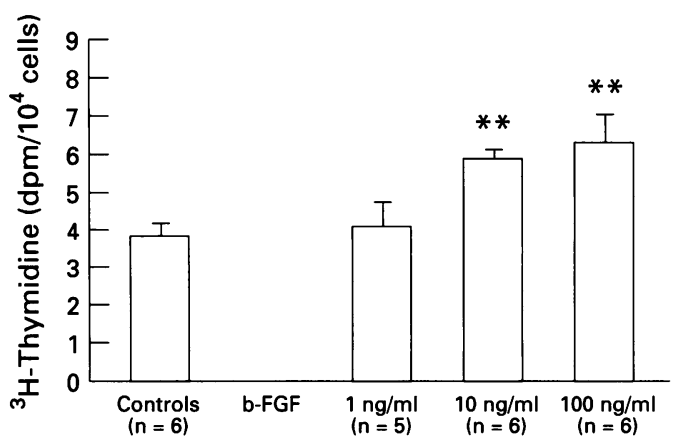

Figure 6 The effects of b-FGF on ${ }^{3} \mathrm{H}$-thymidine uptake by human cataract lens epithelial cells. ${ }^{\star \star}$ Indicates $p<0.01$.

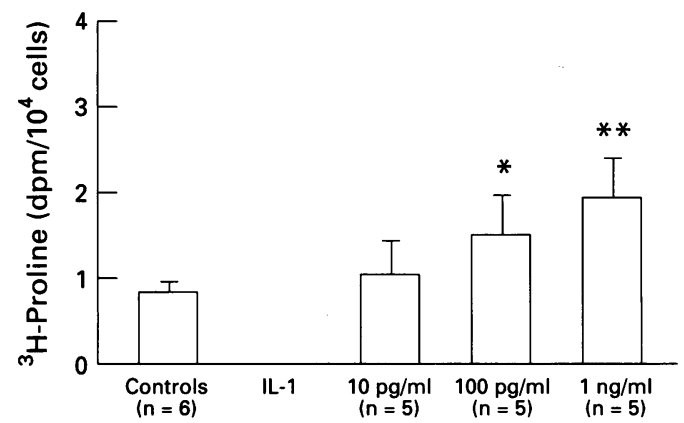

Figure 7 The effects of IL-1 on ${ }^{3} \mathrm{H}$-proline uptake by human cataract lens epithelial cells. ${ }^{\star}$ Indicates $p<0.05$; * indicates $p<0 \cdot 01$.

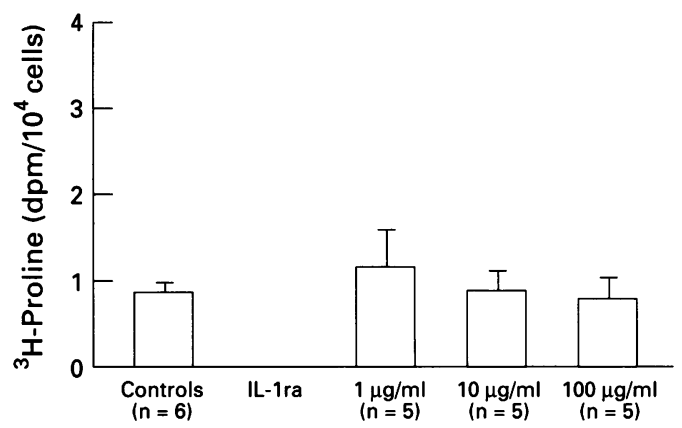

Figure 8 The effects of IL-1ra on ${ }^{3} \mathrm{H}$-proline uptake by human cataract lens epithelial cells.

cells, $\mathrm{x}=$ culture area) with $r$ (coefficient of correlation $)=0.92($ Fig 2$)$.

\section{${ }^{3} \mathrm{H}$-THYMIDINE INCORPORATION AND MITOSIS ASSAY}

The uptake of ${ }^{3} \mathrm{H}$-thymidine was significantly increased by IL-1 at $100 \mathrm{pg} / \mathrm{ml}$ and $1 \mathrm{ng} / \mathrm{ml}$ $(\mathrm{p}<0.01$ for both) (Fig 3$)$, while it was decreased significantly by IL-1 ra at 10 and 100 $\mu \mathrm{g} / \mathrm{ml}$ ( $<<0.01$ for both) (Fig 4). The uptake was significantly decreased by TGF- $\beta 2$ at 100 $\mathrm{pg} / \mathrm{ml}$ and $1 \mathrm{ng} / \mathrm{ml}(\mathrm{p}<0.01$ for both) (Fig 5) and increased by b-FGF at 10 and $100 \mathrm{ng} / \mathrm{ml}$ $(\mathrm{p}<0.01$ for both) (Fig 6).

\section{${ }^{3}$ H-PROLINE INCORPORATION}

The uptake of ${ }^{3} \mathrm{H}$-proline was significantly increased by IL-1 at $100 \mathrm{pg} / \mathrm{ml}(\mathrm{p}<0 \cdot 05)$ and 1 $\mathrm{ng} / \mathrm{ml}(\mathrm{p}<0.01)$ (Fig 7). IL-1 ra did not affect the uptake significantly (Fig 8). The uptake was significantly increased by TGF- $\beta 2$ at 1 $\mathrm{ng} / \mathrm{ml}(\mathrm{p}<0.05)$ and $10 \mathrm{ng} / \mathrm{ml}(\mathrm{p}<0.01)$ (Fig 9) and by b-FGF at $10 \mathrm{ng} / \mathrm{ml}(\mathrm{p}<0.05)$ and $100 \mathrm{ng} / \mathrm{ml}(\mathrm{p}<0.01)$ (Fig 10).

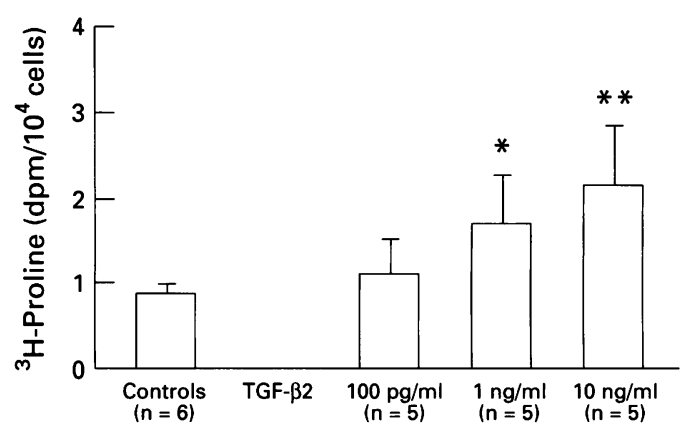

Figure 9 The effects of TGF- $\beta$ on ${ }^{3} \mathrm{H}$-proline uptake by human cataract lens epithelial cells. ${ }^{*}$ Indicates $p<0 \cdot 05$;

**indicates $p<0 \cdot 01$.

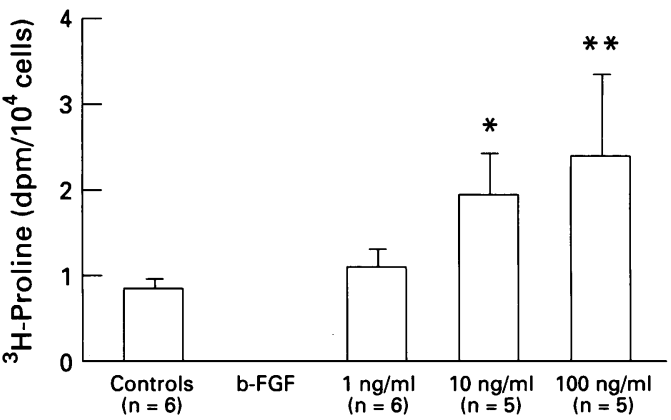

Figure 10 The effects of b-FGF on ${ }^{3} \mathrm{H}$-proline uptake by human cataract lens epithelial cells. ${ }^{\star}$ Indicates $p<0 \cdot 05$; ${ }_{\star}$ indicates $p<0 \cdot 01$.

\section{Discussion}

Our results clearly show that IL-1 increased the mitosis of and synthesis of collagen by human cataract LECs, while IL-1 ra decreased the mitosis significantly. We also reported previously that rabbit polyclonal anti-human IL-1 significantly inhibited the proliferation of human LECs. ${ }^{7}$ Interleukin-1 is now regarded as a basic mediator of intercellular signals, both within the immune system as well as between the immune system and almost all other organ systems, and it possesses a wide spectrum of multifunctional activities. ${ }^{8-10}$ It is known to initiate a cascade of inflammatory mediators. ${ }^{1112}$ It stimulates ${ }^{13-16}$ or inhibits ${ }^{17-19}$ the proliferation of various cells or cell lines. It also increase $^{20-23}$ or inhibits ${ }^{24-28}$ the collagen synthesis in various cell lines. These apparently contradictory results appear to depend on the cell type, the culture conditions, and the presence of other modulating cytokines. IL-1 $\mathrm{ra}^{29}$ has been identified by cloning as the first described naturally occurring endogenous receptor antagonist of any cytokine. It has a molecular weight of 17 to $25 \mathrm{kD}$ and inhibits IL-1 activities by competitive binding to a specific receptor. ${ }^{29} 30$ The dose we used was determined from some reports which indicated that the IL-1 $\beta$ concentration in the anterior chamber at day 7 after intraocular lens implantation in rabbits ${ }^{31}$ was $10 \cdot 12$ (SD 3.96) ng/ml aqueous humour; Rosenbaum et al injected 75 $\mu \mathrm{g}$ of human recombinant IL-1 ra intravitreally in rabbit eyes to assess the potential activity of the IL-1 ra in ocular inflammation by the intravitreal injection of IL-1. ${ }^{32}$ Although IL-1 ra significantly decreased the mitosis rate, it did not affect the collagen synthesis in this study. The collagen synthesis may have been compensated by the collagen synthesis induced by 
cytokines other than IL-1, such as TGF- $\beta$ or bFGF, that are produced by the LECs themselves during culture.

TGF- $\beta 2$ showed a significant suppressive effect on the mitosis, but at the same time increased significantly the collagen synthesis. We reported previously that LEC proliferation was induced by TGF- $\beta$, which, however, was based on the microscopic morphological observation. Both TGF- $\beta$ and b-FGF are involved as pluripotent modulators in embryonic morphogenesis in a number of organs, including the eye, tissue repair, and fibrosis. 103334 TGF- $\beta$ was originally described as a factor that induced phenotypic transformation in fibroblast-like cells. In general, it increases collagen synthesis in a variety of cells or cell lines. ${ }^{35-37}$ TGF- $\beta^{38}$ stimulates the proliferation of cells of mesenchymal origin, but has a suppressive effect on the mitosis of epithelial cells, which is consistent with the present results.

Basic FGF increased significantly the mitosis of and collagen synthesis by human LECs. It stimulates the proliferation and differentiation of a large variety of cells derived from the neuroectoderm, mesoderm, and neural crest. ${ }^{39}{ }^{40}$ It is also capable of angiogenesis. ${ }^{4041}$ Basic FGF appears to participate in the development of the lens. ${ }^{34}$ Cultured corneal endothelial and LECs synthesise b-FGF, ${ }^{40-44}$ which has a mitogenic effect on them. It was detected in the subcapsular epithelium of the lens. ${ }^{4546}$ Basic FGF upregulates $^{444}$ or downregulates ${ }^{4849}$ the collagen synthesis. These effects again appear to depend on the cell type and the culture conditions - that is, whether it is a primary culture or cell line. This property also may be significantly modified by the type of cytokine present.

Interleukin-1 was found in the aqueous humour ${ }^{31}$ in rabbits and IL- $6^{50}$ in humans following intraocular lens implantation. IL-6 is known to be induced by IL- $1 .{ }^{51}$ Basic FGF ${ }^{52}$ and TGF- $\beta^{53-55}$ were detected in the aqueous humour obtained from patients undergoing cataract surgery. Basic FGF was identified ${ }^{56}$ immunohistochemically in the proliferating LECs around the lens capsule after cataract surgery. The above mentioned cytokines may be produced by LECs in vivo as well after cataract surgery, and LECs can be a source of these cytokines detected in the aqueous humour. The cytokines may act in an autocrine or paracrine manner to stimulate or inhibit the proliferation of LECs, enabling them to participate in the formation of a secondary cataract after cataract surgery.

In summary, human recombinant IL-1 increased the mitosis of and collagen synthesis by human cataract LECs in culture, while IL-1ra decreased the mitosis. Basic FGF increased both mitosis and collagen synthesis significantly. TGF- $\beta$ suppressed the mitosis but increased the collagen synthesis significantly. These results suggest that the cytokines synthesised by LECs modulate the proliferation of LECs, enabling them to participate in the formation of secondary cataract after cataract surgery. Illuminating the role of these cytokines in LECs may lead potentially to the development of new therapies to inhibit their proliferation and, therefore, to prevent secondary cataract.

The authors have no proprietary interest in the methods and products mentioned in this paper.

1 Nishi O, Nishi K, Imanishi M. Synthesis of interleukin-1 and prostaglandin $E_{2}$ by lens epithelial cells of human cataracts. Brf Ophthalmol 1992; 76: 338-41.

2 Nishi K, Nishi O, Ohmoto Y. The synthesis of cytokines by human lens epithelial cells. Interleukin-1, tumor necrosis factor, interleukin-6, and epidermal growth factor Acta Soc Ophthalmol fpn 1992; 96: 715-20.

3 Nishi K, Nishi O. Basic fibroblast growth factor detected by ELISA during the time course of human cataract lens cell culturing. Atarashii Ganka 1994; 11: 143-5.

4 Nishi O, Hanasaki K. Automated morphometry of corneal endothelial cell: use of video camera and video tape recorder. Br $\mathcal{F}$ Ophthalmol 1988; 72: 68-73.

5 O'Keefe EJ, Chin ML, Payne RE. Stimulation of growth of keratinocytes by basic fibroblast growth factor. $\mathcal{F}$ Invest Dermatol 1988; 90: 767-9.

6 Agelli M, Wahl SM. Collagen production by fibroblast. In: Giovanni Di Sabato, ed. Methods in enzymology. New York: Academic Press, 1989; 163: 642-6.

7 Nishi K, Nishi O, Imanishi M. Induction of prostaglandin $\mathrm{E}_{2}$ by interleukin-1 in human lens epithelial cells. Acta So Ophthalmol fpn 1993; 97: 156-61.

$8 \mathrm{Di}$ Giovine FC, Duff GW. Interleukin 1: the first interleukin. Immunol Today 1990; 11: 13-20.

9 Oppenheim J, Ruscetti FW, Faltinek C. Cytokines. In: Stites DP, Terr AI, eds. Basic human immunology. East Norwalk: Appleton and Lange, 1991: chapter 7.

10 De Vos AF, Hoekzema R, Kijlstra A. Cytokines and uveitis, a review. Curr Eye Res 1992; 581-97.

11 Ferrick MR, Thuran SR, Oppenheim MH, Herbort CP $\mathrm{Ni} \mathrm{M}$, Zachariae COC, et al. Ocular inflammation stimulated by intravitreal interleukin- 8 and interleukin-1. Invest Ophthalmol Vis Sci 1991; 32: 1534-9.

12 Rosenbaum JT, Samples JR, Hefeneiber SH, Homes EN Jr. Ocular inflammatory effects of intravitreal interleukin-1. Arch Ophthalmol 1987; 105: 1117-20.

13 Therry $C$, Mallat $M$. Influence of interleukin-1 and tumor necrosis factor alpha on the growth of microglial cells in primary cultures of mouse cerebral cortex: involvement of primary cultures of mouse cerebral cortex: involvement of colony-stin

14 Hanley N, Williams BC, Nicol M, Bird IM, Walker SW Interleukin-1 beta stimulates growth of adrenocortica cells in primary culture. $\mathcal{F}$ Mol Endocrinol 1992; 8: 131-6.

15 Mine M, Tramontano D, Chin WW, Inghar SH Interleukin-1 stimulates thyroid cell growth and increases the concentration of the $\mathrm{C}$-myc proto-oncogene mRNA in thyroid follicular cells in culture. Endocrinology 1987; 120: 1212-4.

16 Chiplunkar S, Langhorne J, Kaufmann SH. Stimulation of $B$ cell growth and differentiation by murine recombinant interleukin 1. F Immunol 1986; 137: 3748-52.

17 Ikeda $M$, Ikeda U, Kano S. Interleukin 1 suppresses mesangial cell growth via inhibition of $\mathrm{Ca}^{2+}$ entry. Cytokine 1991; 3: 131-3.

18 Cozzolino F, Torcia $M$, Aldinucci D, Ziche $M$ Almerigogna $\mathrm{F}$, Bani $\mathrm{D}$, et al. Interleukin 1 is an autocrine regulator of human endothelial cell growth. Proc Nat Acad Sci USA 1990; 87: 6487-91.

19 Chin JE, Lin YA. Effects of recombinant human interleukin 1 beta on rabbit articular chondrocytes. Stimulation of prostanoid release and inhibition of cell growth. Arthritis prostanoid release and in

20 Krane SM, Goldring MB. Potential role of interleukin-1 in fibrosis associated with chronic ambulatory peritoneal dialysis. Blood Purif 1988; 6: 173-7.

21 Zhang Y, Lee TC, Guillemin B, Yu MC, Rom WN Enhanced IL-1 beta and tumor necrosis factor-alpha release and messenger RNA expression in macrophage from idiopathic pulmonary fibrosis or after asbestos exposure. $f$ Immunol 1993; 150: 4188-96.

22 Bodo M, Venti G, Pezzetti F, Ardisia C, Antonica A Carinci $\mathrm{F}$, et al. Interleukin-1 alpha: regulation of cellular proliferation and collagen synthesis in cultured human proliferation and collagen synthesis in cultured hu
osteoblast-like cells. Cell Mol Biol 1992; 38: 679-86.

23 Martens MF, Hyken CM, Hendriks T. Collagen synthesis in fibroblasts from human colon: regulatory aspects and differences with skin fibroblasts. Gut 1992; 33: 1664-70.

24 Bureau J, Fabre EJ, Hecquet C, Pouliquen Y, Lorans G. Modification of prostaglandin $E_{2}$ and collagen synthesis in keratoconus fibroblasts, associated with an increase of interleukin 1 alpha receptor number. CR Acad Sci III 1993; 316: 425-30

25 Okada Y, Katsuda S, Watanabe H, Nakanishi I. Collagen synthesis of human arterial smooth muscle cells: effects of platelet-derived growth factor, transforming factor-beta 1 and interleukin-1. Acta Pathol fpn 1993; 43. 160-7.

26 Diaz A, Munoz E, Johnston R, Korn JH, Jimenez SA. Regulation of human lung fibroblast alpha 1 procollagen gene expression by tumour necrosis factor-alpha, intergene expression by tumour necrosis factor-alpha, inter263: 10364-71.

27 Suzama H, Kikuchi S, Ichikawa K, Koda A. Inhibitory action of tranilast, an anti-allergic drug on the release of 
cytokines and $\mathrm{PGE}_{2}$ from human monocytesmacrophages. Fpn f Pharmacol 1992; 60: 85-90.

28 Armendariz-Borunda J, Katayama K, Seyer JM

Transcriptional mechanisms of type I collagen gene expression are differentially regulated by interleukin-1 beta tumor necrosis factor alpha, and transforming orowth factor beta in Ito cells. $\mathcal{F}$ Biol Chem 1992; 267: 14316-20.

29 Hannum CH, Wilcox CJ, Arend WP, Fennecke G, Joslin

DT, Dripps PL, et al. Interleukin-1 receptor antagonist DT, Dripps PL, et al. Interleukin-1 receptor antagonist 343: 336-40.

30 Arend WP. Interleukin receptor antagonist. Adv Immunol 1993; 54: 167-227.

31 Yokoyama $\mathrm{T}$. Interleukin-1 in the aqueous humor in aphakic and psendophakic eyes of rabbits. Acta Soc Ophthalmol fpn 1992; 96: 67-73.

32 Rosenbaum JT, Boney RS. Activity of an interleukin receptor antagonist in rabbit models of uveitis. Arch Ophthalmol 1992; 100: 547-9.

33 Tripathi BJ, Tripathi RC, Livingston AM, Borisuth NSC The role of growth factors in the embryogenesis and differentiation of the eye. Am 7 Anat 1991; 192: 442-71.

34 McAvoy JW, Chamberlain CG. Growth factors in the eye. Prog Growth Factor Res 1990; 2: 29-43.

35 Davidson JM, Zoia O, Liu JM. Modulation of transforming growth factor-beta 1 stimulated elastin and collagen production and proliferation in porcine vascular smooth muscle cells and skin fibroblasts by basic fibroblast growth factor, transforming growth factor-alpha, and insulin-like growth factor-1. ₹ Cell Physiol 1993; 155: 149-56.

36 Bollireni JS, Reddi AS. Transforming growth factor-beta 1 enhances glomerular collagen synthesis in diabetic rats. Diabetes 1993; 42: 1673-7.

37 Ritzenhaler JD, Goldstein RH, Fine A, Smith BD. Regulation of the alpha 1 collagen promoter via a trans forming growth factor-beta activation element. $\mathcal{f}$ Biol Chem 1993; 268: 13625-31.

38 Antonelli-Orlidge A, Saunders KB, Smith SR, D'Amore PA. An activated form of transforming growth factor $\beta$ is produced by cocultures of endothelial cells and pericytes. Proc Natl Acad Sci USA 1989; 86: 4544-8.

39 Gospodarowicz D, Neufeld G, Schweigerer L. Fibroblast growth factor. Mol Cell Endocrinol 1986; 46: 187-204.

40 Gajdusek CM, Luo Z, Mayberg MR. Basic fibroblast growth factor and transforming growth factor beta-1: synergistic mediators of angigenesis in vitro. $\mathcal{F}$ Cell Physio 1993; 157: 133-44

41 Villaschi S, Nicosia RF. Angiogenic role of endogeneous basic fibroblast growth factor released by rat aorta after injury. Am f Pathol 1993; 143: 181-90.

42 Schweigerer L, Ferrara N, Haaparanta T, Neufeld G, Gospodarowicz D. Basic fibroblast growth factor: expression in cultured cells devised from corneal endothelium and lens epithelial. Exp Eye Res 1988; 46: 71-80.

43 Tripathi RC, Kolli S, Tripathi BJ. Fibroblast growth factor in the eye and prospects for its therapeutic use. Drug Dev Res 1990; 19: 225-37.

44 Kay EP, Gu X, Ninomiya Y, Smith RE. Corneal endothelial modulation: a factor released by leukocytes induces basic fibroblast growth factor that modulates cell shape and collagen. Invest Ophthalmol Vis Sci 1993; 34: 663-72.

45 Caruelle D, Groux-Muscatelli B, Gaudric A, Sestier C, Coscas G, Caruelle JP, et al. Immunological study of acidic fibroblast growth factor (aFGF)

eye. 7 Cell Biochem 1989 udouin C, Fredj-Reygrobe D, Gastand P, Lapalus P. Acidic fibroblast growth factor distribution in normal human eye and possible implications in ocular pathogenesis. Ophthalmic Res 1990; 22: 73-81.

47 Wu LN, Genge BR, Ishikawa Y, Wuthier RE. Modulation of cultured chicken growth plate chondrocytes by transforming growth factor-beta 1 and basic fibroblast growth factor. F Cell Biochem 1992; 49: 181-98.

48 Majors A, Ehrhart LA. Basic fibroblast growth factor in extracellular matrix suppresses collagen synthesis and type III procollagen mRNA levels in anterial smooth muscle cell cultures. Arterioscler Thromb 1993; 13: 680-6.

49 Tan EM, Rouda S, Greenbaum SS, Moore JHJr, Fox JW 4th, Sollberg S. Acidic and basic fibroblast growth factors down-regulate collagen gene expression in heloid fibroblasts. Am F Pathol 1993; 142: 463-70.

50 Malecaze F, Chollet P, Cavrois E, Vita N, Arrie JL, Ferrara P. Role of interleukin 6 in the inflammatory response after cataract surgery. An experimental and clinical study. Arch Ophthalmol 1991; 109: 1681-3.

51 May LT, Torua C, Cozzolino F. Interleukin-6 gene expression in human endothelial cells: RNA start sites, multiple IL-6 proteins and inhibition of proliferation. Biochem Biophys Res Commun 1989; 159: 991-8.

52 Tripathi RC, Millard CB. A molecule resembling fibroblast growth factor in aqueous humor. Am $\mathcal{F}$ Ophthalmol 1988; 106: $230-1$

53 Jampel HD, Roche N, Stark WJ, Roberts AB. Transforming growth factor- $\beta$ in human aqueous humor. Curr Eye Res 1990; 9: 963-9.

54 Cousins SW, McCabe MM, Danielpour D, Streilein JW. Identification of transforming growth factor-beta as an immunosuppressive factor in aqueous humor. Invest Ophthalmol Vis Sci 1991; 32: 2201-11.

55 Granstein $R D$, Staszewski $R$, Knisely EZ, Zeira E, Nazareno $R$, Latina $M$, Albert DM. Aqueous humor contains transforming growth factor $\beta$ and a small $(<3500$ daltons) inhibitor of thymocyte proliferation. $\mathcal{f}$ Immunol 1990; 144: 3021-7.

56 Hayashi N, Kato H, Kiyosawa T, Hayashi H, Oshima K, Yamaoka $M$. The change of immunohistochemical localization of basic fibroblast growth factor around the lens capsule after extracapsular extraction. Acta Soc Ophthalmol fpn 1991; 95: 621-4. 